\title{
ASSESSMENT OF FLUORIDE PROPHYLAXIS IN CHILDREN WITH MIXED DENTITION IN CONNECTION WITH THE RISK OF EARLY TOOTH LOSS
}

\author{
Radosveta Andreeva \\ Department of Pediatric Dentistry, Faculty of Dental Medicine, \\ Medical University of Varna
}

\begin{abstract}
Properly implemented fluoride provides up to 80 percent reduction of dental caries, its complications and respectively premature tooth loss. The aim of the study is to assess fluoride prophylaxis in children with mixed dentition in connection with the risk of early tooth loss. Subject of monitoring of the clinical research were 140 school children with mixed dentition. The clinical group consists of 90 children with prematurely extracted teeth. The patients from the clinical group were divided into three groups of 30 patients. The control group consists of $\mathbf{5 0}$ children with intact denture. A special questionnaire was filled out by the parents of the examined child about the usage of fluoride prophylaxis (endogenous and exogenous intake of fluoride). The results showed that a very small percentage of children had received optimal fluoride prophylaxis (endogenous and exogenous) $-\mathbf{2 0} \%$. They were all in the control group. The children from the clinical groups used only fluoride toothpaste as a fluoride prophylaxis - about $78 \%$. About $31 \%$ of them do not use any form of fluoride, even in the toothpaste, especially the children from the third group - $33.3 \%$. Conclusion: The lack of fluoride prophylaxis leads to more premature extractions among the children with mixed dentition.
\end{abstract}

Keywords: fluoride; prophylaxis; early tooth loss

\section{INTRODUCTION}

The trends of modern dentistry are directed to preventing caries and its complications that lead to early tooth loss. The preventive measures include fluoride and nutritional prevention and oral hygiene. Fluoride enters the human body through food and

\footnotetext{
Address for correspondence:

Radosveta Andreeva

Faculty of Dental Medicine,

Medical University of Varna

55 Marin Drinov Str.

9002 Varna, Bulgaria

e-mail:doctor_ra@abv.bg
}

Received: September 5, 2016

Accepted: December 18, 2016 water. About $50 \%$ of it is deposited in bones and teeth and has a physiological effect mainly on their mineralization $(1,2)$. Fluoride prevention could be exogenous and endogenous. The endogenous one comprises administering prophylactic doses of fluoride in the digestive tract by fluoridated water, milk and salt or tablets. Exogenous fluoride is administered by a dentist by topical application of fluoride preparations or by the patient by using toothpaste (3).

The impact of fluoride on teeth is throughout their formation and growth. During the formation of the enamel of the teeth, the fluoride ion binds to the hydroxyapatite of the enamel and becomes a fluoridehydroxyl-apatite. It is an acid resistant compound. Thanks to it, the risk of caries and premature tooth loss has decreased $(4,5)$. In certain doses, fluoride 
has many beneficial effects against caries lesions: it is able to limit demineralization and promote remineralization instead of the tooth. Moreover, it inhibits the growth of bacteria responsible for tooth decay $(6,7)$.

The aim of the study is to assess fluoride prophylaxis in children with mixed dentition in connection with the risk of early tooth loss.

\section{MATERIALS AND METHODS}

Subject of monitoring of the clinical research were 140 school children with mixed dentition. The clinical group consists of 90 children with prematurely extracted teeth. The patients from the clinical group were divided into three groups of 30 patients. The control group consists of 50 children with intact denture. $\diamond \quad$ A special questionnaire was filled out by the parents of the examined child about the usage of fluoride prophylaxis (endogenous and exogenous intake of fluoride).

\section{RESULTS}

The results showed that a very small percentage of children had received optimal fluoride prophylaxis (endogenous and exogenous) - 20\%. They were all in the control group. The children from the clinical groups used only fluoride toothpaste as a fluoride prophylaxis - about $78 \%$. About $31 \%$ of them did not use any form of fluoride, even in the toothpaste, especially the children from the third group $-33.3 \%$. The distribution of children according to fluoride usage is presented in the following table (Table 1).

Table 1. Distribution of children from the surveyed groups depending on the type of fluoride prophylaxis and its presence or absence

\begin{tabular}{|c|c|c|c|c|c|c|c|c|}
\hline \multirow[b]{3}{*}{ Group } & \multicolumn{6}{|c|}{ Has there been a fluoride prophylaxis } & & \\
\hline & \multicolumn{2}{|c|}{ No } & \multicolumn{2}{|c|}{ Fluoride toothpaste } & \multicolumn{2}{|c|}{$\begin{array}{l}\text { Endogenous flour pro- } \\
\text { phylaxis and fluoride } \\
\text { toothpaste }\end{array}$} & \multicolumn{2}{|c|}{ Total } \\
\hline & Number & $\%$ & Number & $\%$ & Number & $\%$ & Number & $\%$ \\
\hline Control group & 1 & 2.0 & 38 & 77.6 & 10 & 20.4 & 49 & 100 \\
\hline Group 1 & 3 & 10.7 & 25 & 89.3 & 0 & 0.0 & 28 & 100 \\
\hline Group 2 & 6 & 20.0 & 24 & 80.0 & 0 & 0.0 & 30 & 100 \\
\hline Group 3 & 10 & 33.3 & 20 & 66.7 & 0 & 0.0 & 30 & 100 \\
\hline $\begin{array}{l}\text { Statistical } \\
\text { significance }\end{array}$ & & & $\chi^{2}=32.3$ & 0.00 & & & & \\
\hline
\end{tabular}

$\diamond$ Patients who have lost one or more tooth through extraction and have come to the clinic during the first 2 months after the extraction and have no orthodontic problems.

$\diamond$ Patients with prematurely temporary teeth extracted 6 or more months prior with mild orthodontic problems.

$\diamond$ Patients with prematurely temporary tooth loss 6 or more months prior and have severe orthodontic problems (II and III class Angle).

$\diamond$ The control group consists of 50 children of the same age who have no premature extractions.
Statistically significant difference was found in the distribution of groups according to the presence of fluoride and the type of fluoride prophylaxis $\left(\chi^{2}=32.3, \mathrm{df}=6, \mathrm{P}<0.0001\right)$. In the control group almost all children took fluoride, but in the clinical groups a significant proportion of children did not use such a prevention.

\section{DISCUSSION}

Fluoride has a main role in the creation of healthy enamel of the teeth. The fluoride prophylaxis has been neglected by the parents of the children with prematurely lost teeth. That is the reason for the carious activity and respectively premature 
extraction of children without fluoride prevention. The optimal fluoride prophylaxis (endogenous and exogenous) is one of the main preventive measures against the dental caries and the early tooth loss $(8,9,10)$.

\section{CONCLUSSION}

The lack of fluoride prophylaxis leads to more premature extractions among the children with mixed dentition.

\section{REFERENCES}

1. Peneva M, Colova E, Kabakchieva R, Rashkova M. Prophylaxis of oral diseases. Pediatric dentistry book. Sofia, 2007;122-123.

2. Moss S. Saliva, fluorid, diet, evolution: a new caries model emerge. Italian J. of Pediatric dentistry. 1998;1:19-24.

3. Alshemiti BD, Hughes S. Reasons for dental extraction in children. Pediatric Dent. 2001;23:109-112.

4. Ferro F. Factors associated with premature tooth loss. Pediatr. Dent. 2000;18:237-239.

5. Mathewson JR, Primosch RE. Fundamentals of Pediatric Dentistry. Quintessence publishing Co, 3rd edition.1995;326-338.

6. Kidd, E. Essentials of dental caries in connection with fluoride prevention. The disease and its management, 3 ed. 2005;2-3.

7. Kandiah T, Johnson J, Fayle SA. British Society of Paediatric Dentistry: a policy document on management of caries in the primary dentition. Int J Paediatr Dent. 2010;20(1):5.

8. Inglehart M, Habil P. Oral health - related on the quolitiy of life and fluoride usage. Списание! 2002;80-87.

9. Saravanan S, Kalyani V, Jayakodi P. Caries prevalence and the treatment need of rural school shildren, South India. Indian J Dent Res. 2009;19:186-90.

10. Drury T, Horowitz A. Diagnozing and reporting early child caries in connection with lack of fluoride for research purpose. J.Publ.Health Dent.1999;59:192-197. 